\title{
Vedení procesů organizačního učení ve škole: př́ípadové studie
}

Leading processes of organisational learning at schools: case studies

\author{
Milan Pol, Lenka Hloušková, Martin Sedláček, Bohumíra Lazarová, \\ Petr Novotný
}

\begin{abstract}
Abstrakt: V příspěvku představujeme dílčí výsledky další fáze výzkumného projektu Procesy organizačního učení ve škole a jejich vedení ${ }^{1}$. Ve druhé fázi řešení projektu byl zahájen empirický výzkum v základních školách, jehož cílem je poznat organizační učení ve škole a získat elementární přehled o stimulech a bariérách organizačního učení. Výzkumným designem kvalitativně orientované druhé fáze byla zvolena př́padová studie. V tomto př́spěvku budou detailněji projednány výsledky prvních dvou prŕípadových studií.
\end{abstract}

Klíčová slova: škola, organizační učení, vedení škol,

\begin{abstract}
The text deals with results of the second phase of the research project Processes of organisational learning at schools and their leadership. In this phase the empirical research has been started at basic schools (6-15) witht he aim to identify organisational learning at schools and to get basic overview about stimuli and also possible hindrances of organisational learning. The research design is case study. In this text we inform in a more detail about results of the first two case studies.
\end{abstract}

Keywords: school, organisational learning, school leadership

\section{1 Úvod}

Ve shodě s mnoha autory nahlížíme na organizační učení jako na jeden z hlavních atributů rozvoje školy (srov. Leithwood \& Louis, 1998; Dalin, Rolff, \& Kleekamp, 1993; Pol, 2007). Cílem př́spěvku je ukázat prvotní výsledky z první kvalitativně orientované fáze empirického výzkumu. V textu prezentujeme dílčí výsledky analýz - doposud víceméně popisných $\mathrm{z}$ realizovaných prvních dvou príípadových studií. ${ }^{2}$

\section{Organizační učení a kapacita k organizačnímu učení jako východisko pro interpretaci př́padových studií}

V některých teoretických diskuzích o organizačním učení ve školách se zdůrazňuje užitečnost dvojího vnímání procesů organizačního učení: (1) skrze samotné učení, jeho konkrétní průběh, témata, iniciační momenty a efekty tohoto učení; (2) skrze existující podpůrné organizační struktury, sítě interakcí, mechanismy sdílení praxe a slad'ování hodnot atd., tzn. skrze existující kapacity k učení (srov. Goh, Cousins, Elliott, 2006). Při analýze dat se

\footnotetext{
${ }^{1}$ Projekt je financovaný GA ČR, realizovaný v letech 2010-1012 a vedený pod číslem projekt GAP407/10/1197.

${ }^{2} Z$ důvodu pokrytí hlavních východisek i získání větší nasycenosti budou v rámci řešení projektu realizovány studie celkově tří základních škol, jejichž výsledky budou dále rozvíjeny v další kvantitativně zacílené fázi výzkumu.
} 
rozlišení organizačního učení a kapacity k organizačnímu učení ukázalo jako nosné a stalo se vodítkem při určování struktury prezentace dat $v$ tomto textu. Demonstrujeme tím přesvědčení, že procesy organizačního učení jsou závislé na fungování podpůrných organizačních struktur učení, vedení organizačního učení, vnímání významu učení a jeho užitečnosti aktéry školního života. Kapacitou pro organizační učení máme na mysli sestavu či systém atributů školy podporujících organizační učení (srov. Goh, Cousins, Elliott, 2006; Collinson, Cook, Conley, 2006; Verbiest, 2002; atd.). Takto popsanou sestavu atributů lze dále strukturovat do tř́ dimenzí kapacity $k$ organizačnímu učení ve škole (srov. Verbiest, 2002):

- Organizační kapacita, kterou přestavují zdroje, organizační struktury a systémy učení; vnímaný význam učení; vedení/řízení.

- Interpersonální kapacita, tzn. charakter komunikace a interakce; kolektivní učení a sdílená praxe.

- Individuální kapacita, která je vyjádřena mírou a charakterem reflexe učení a jeho př́nosu; propojením individuálního učení s potřebami školy.

\section{Metodologické poznámky}

Případovou studii vnímáme jako postup, který nejlépe umožňuje porozumění komplexnosti př́padu - v našem výzkumu procesu organizačního učení - $v$ jeho přirozeném prostředí (srov. Stake, 1995; Yin, 2003; Sedláček 2007). Výsledky analýzy této kvalitativní fáze se stanou opěrným bodem - zdrojem hypotéz - pro následný kvantitativně orientovaný výzkum (srov. Yin, 2003; Miovský, 2006).

První vybraný případ označujeme jako školu A. Podle Yinovy (2003) typologie jde o tzv. kritický př́pad. Šlo nám o školu, kde lze očekávat dostatečný prostor pro učení se, potažmo pro rozvoj. Teorie upozorňuje v tomto na důležitou roli vedení školy (srov. Marsick \& Watkins, 1994). Na základě analýz zpráv ČŠI a expertních konzultací jsme vybrali školu ve větším městě, která vykazovala znaky dobře řízené a vedené školy s dobrou image v okolí. Sběr a analýza dat probíhal v lednu až květnu 2011. Následně jsme rozhodli, že kritériem pro výběr druhého př́padu - školy $B$ - bude strategie tzv. kontrastního př́padu. Hledali jsme školu, kde vedení školy nebylo z nějakého důvodu dostatečně etablované. Vybrali jsme městskou školu, ve které v době šetření (květen až červen 2011) byli členové vedení školy ve svých funkcích teprve půl roku.

Hlavní technikou sběru dat v obou školách se staly hloubkové rozhovory se všemi klíčovými dospělými aktéry. Rozhovory (často opakované) byly vedeny s řediteli, jejich zástupci, řadou učitelů a vychovatelkami. Triangulačními metodami sběru dat byly analýzy školních dokumentů a terénní poznámky pořizované v průběhu návštěv škol. Rozhovory jsme nahrávali na diktafon a následně byly celé přepsány. Stejně jako ostatní datový materiál pak byly zpracovány v programu ATLAS.ti. Analýza byla prováděna tak, že nejprve byl datový materiál podroben technice otevřeného kódování. Výsledkem bylo identifikování klíčových kategorií, které jsme následně začali deskriptivně zpracovávat a to v souvislosti s našimi výzkumnými otázkami. Zde se orientujeme na tyto otázky: Proč se dospělí ve škole učl? Co se lidé ve škole učí? Jak se dospěli ve škole učí? Jak a čím je učení podporováno? Jaká je kapacita škol pro organizační učení na úrovni organizační, interpersonální a individuální? 


\section{$4 \mathrm{Z}$ výsledků: škola $A$}

\subsection{Charakteristika školy $A$}

Úplná základní škola se školní družinou je ve velkém městě. Počet žáků osciloval v posledních letech kolem 500. Škola je v okolí vnímána jako relativně úspěšná škola. Ředitelka školy společně se svými zástupci působila ve funkci v této škole 7 roků. Hodnotící zpráva ČŠI vyznívá pro školu velmi pozitivně, vedení školy je hodnoceno jako stabilní, podpora dosahování vzdělávacích cílů učiteli a oblast školního poradenství jako nadstandardní.

Škola se profiluje jako škola s rozšířenou výukou anglického jazyka (na I. stupni) a s rozšířenou výukou přírodovědných předmětů, matematiky a informatiky (na II. stupni). Na I. stupni jsou paralelní ročníky s programem jedné z klasických alternativ. Pedagogický sbor tvoři 38 pracovníků, z toho 36 kvalifikovaných, plus 16 nepedagogických pracovníků. Specifikem sboru je relativně výrazná obměna, v posledních 5 letech se vyměňuje kolem 3 učitelů za rok, což vedlo k posílení nejmladší skupiny pedagogických pracovníků (do 35 let).

\subsection{Iniciační momenty organizačního učení}

Přestože učitelé a vychovatelé o svém učení, o profesním rozvoji v prvním plánu nehovoří, a stejně tak zástupci vedení školy nepoukazují na to, že by jejich cílem byl ideál učící se školy, je škola A organizací, ve které je proces učení, myšleno nejen u žáků, silně zastoupen. Analýza získaných dat naznačuje, že toto učení, snaha o individuální a ve vztahu s ním i o organizační rozvoj, má primárně dva zdroje. V prvé řadě jde o stálý tlak vedení školy v podobě dobře implementované vize. Ředitelka společně se svými zástupci velmi cílevědomě usiluje o budování kvalitní školy, která bude úspěšná a bude vidět. Tohoto úspěchu má být dosahováno především kvalitní nabídkou vzdělávacího programu školy. S tím souvisí i tlak na kvalitní práci učitelů a vychovatelů. Tato vize, se kterou ředitelka se svým statutárním zástupcem do školy nastupovala, se postupně realizuje. Přes počáteční odpor řady pedagogů školy se zdá, že dnes ve škole většina tento cíl podporuje či alespoň přijímá.

Dlouhodobě podporované vědomí př́slušnosti ke škole je druhým stěžejním motivem. U některých učitelů je zcela zjevným stimulem jejich profesního rozvoje snaha být součástí dobrého jádra školy. Výpovědi ukazují, že pro učitele má hodnotu status dobrého učitele. Snaha získat a udržet takovou pozici je druhým hnacím motorem pro učení se ve škole i pro školu. Přijetí vize a postupné přizpůsobení se sboru vystihuje i vyjádření zástupce ředitelky.

TAZATEL: „A ostatni ve škole to vidi stejně? Myslím tím, že nemají problém vstupovat do těch projektü, podilet se na aktivitě? “

ZÁSTUPCE ŘEDITELKY (škola A): „, Myslím, že u nás ve sboru už jo, ale ten začátek byl hroznej. Taky, řekl bych, nemalá část sboru odešla. Jednak už šli do důchodu, ale někteři i sami odešli. Vétšinou z prvniho stupně teda, tam to bylo takový ještě horší. Tam totiž na ty lidi jako kdyby nebylo nikdy vidět, protože na tom prvním stupni, to je myslím problém všech základnich škol, který jedou takovým tím samospádem.... Ne všichni si s tím naším pojetím sedli od začátku vůbec ne. Jednak se to postupně tř́dilo, ale hlavně jsme o tom mluvili. Zavedli jsme hodně hospitace a pořád jsme to řešili, to bylo hlavně třeba to ŠVP. Někteři se ale chytli, ne všichni, ale je tady jádro, co dnes sami chodí, a navrhne, vidéla jsem toto, co kdybych to zkusila. "

\subsection{Identifikovaná témata organizačního učení}

Z dat lze identifikovat dílčí tematické oblasti. Stěžejním je kurikulární reforma, konkrétně školní vzdělávací program (ŠVP), který je chápán jako př́iležitost ukázat kvalitu. Škola tak 
byla již jednou z pilotních škol. Práce na ŠVP má průběžný ráz, každoročně se inovuje jedna oblast (v době šetření se intenzivně pracovalo na reformulaci kritérií pro hodnocení). Vedením školy vyžadovaná kontinuální práce na ŠVP je častým tématem komunikace mezi učiteli např́íč školou. Druhým tématem je problematika metodiky pedagogické práce (různé „fígle“, práce s problémovými žáky jsou ve škole sdíleným tématem). Informační a komunikační technologie (ICT) a jejich uplatnění tvoří třetí obsahovou oblast učení. ICT jsou v popředí ze dvou důvodů: (a) stávají se běžnou součástí kultury školy, používají se pro vzájemnou komunikaci, pro komunikaci s veřejností apod.; (b) ovlivňují denní práci učitelů (ve škole se zkouší elektronické žákovské knížky). Mladší učitelé zde jsou nezřídka nápomocni zkušenějším kolegům. Prostřednictvím těchto dominantních ale i dalších dílčích subtémat je ve škole „,předmětem učeni““ ještě jedno silné průřezové téma. Jde o téma kultury. Škola má jasnou vizi a klade na všechny ve škole značné nároky. Nově př́íchozí se učí existovat $\mathrm{v}$ tomto prostoru, pronikat do kultury a podílet na jejím dalším spoluvytváření.

\subsection{Organizační, interpersonální a individuální kapacita k učení}

Vedení školy se snaží vytvářet přiměřené podmínky pro jeho naplnění dlouhodobých cílů. Ve škole funguje metodické sdružení i předmětové komise, jejichž činnost má reálnou náplň obsahově se zaměřují především na ŠVP. Ředitelka zavedla a podporuje vzájemné hospitace mezi učiteli, které jsou mj. platformou pro vzájemné učení. Tato praxe není ve škole přijímána absolutně, má ale své výsledky, což ukazuje i následující výrok.

TAZATEL.: , Jak vy vidite ty vzájemné hospitace? Vadi Vám to, přináši to něco? “

UČITELKA (I. stupeň, 8 let praxe, škola A): „Tak ono to samozřejmě někomu nevyhovuje. On taky nikdo není jako nucen. Já to taky extra nevyuživám. Někdy je to taky těžké i sladit...v rozvrhu. Ale třeba ted' byla jsem v páté třídě, protože vím, že do páté třídy přiští rok půjdu, pưjdu učit do páté třídy, tak mě to zajímalo a šla jsem se podivat do páté tř́dy. Já jsem nic nepotřbovala, kolegyně souhlasila, nic si nechystala pro mě. Šlo mně spiš o to, jak ty děcka něco časově zvládaji. "

Nelze říci, že škola z hlediska organizační kapacity funguje zcela bezproblémově. Patrné jsou i potenciální bariéry. Př́kladem můžou být stavebně nepropojené budovy školy, což v sobě nese riziko izolace učitelů. Jiným rizikem by mohlo být možné soupeření učitelů na prvním stupni z důvodu existence dvou programů. Analýza dat ukazuje, že veškerá tato organizační kapacita, at' už ve formě pozitiv či rizik, nehraje ve škole rozhodující roli. Mnohem významnější je naplněný potenciál interpersonální kapacity, poháněný výše uvedenými stimuly (vize, pocit sounáležitosti). Pominout nelze ani individuální kapacitu jednotlivých aktérů školního života. Tu ovšem v tomto šetření poznáváme jen zprostředkovaně.

\subsection{Jak je organizační učení ve škole podporováno?}

Podpora kontinuálního rozvoje na úrovni jednotlivce i školy se zdá být pevná. Hlavním prostředkem vedení školy je dobrá implementace své vize. Jedním z nástrojů, pomocí kterého se podařilo ředitelce a jejímu týmu vtáhnout celou školu, je strategie delegování. Ve škole je běžné, že jsou podstupovány důležité pravomoci i „,̌̆adovému“ učiteli. Tento styl s sebou nese větší zapojení, zároveň zvyšuje individuální nároky na každého.

ŘEDITELKA (škola A):,,Jeden kolega, co uči informatiku a fyziku, tehdy přišel, že by rád zkusil projekt v ESF schématu na e-learningovou podporu. "

TAZATEL.: „Jaká je vaše role v tom projektu? “

$\check{R}$ : „Jenom podporující, já jsem to nadšeně príijala, ale nijak v tom nefiguruji. “

$T:$,A funguje to jak? “ 
$\check{R}:$ „,Koordinuje to ten pan učitel, on pak určil garanty jednotlivých předmětů.V̌̌echno ale schvaluje on. Přiděluje tam i odměny. Jsem s tím spokojená. “

Podpora vedení se ukazuje i v řadě jiných př́kladů. Za zmínku stojí ještě jeden významný školy - relativně cílená personální politika. Vedení si do jisté míry uvědomuje náročnost svého pojetí a snaží se, aby vize byla skutečně sdílena např́ič školou. Ne vždy ale nachází absolutní pochopení. V případech neporozumění dochází i k ochodům ze školy.

UČITELKA (I. stupeñ, 8 let praxe, škola A): „Myslím si, že kdybych to tak rozvrhla na procenta, tak osmdesát procent ano, dvacet procent ne. To je alespoň můj názor. Myslím si, že jo. A dalo by se ř́ct, že kdo se s tím jako by neztotožnil, tak odešel ze školy. Zkrátka se s tím neztotožnil, nebyla to nějaká jeho vize."

\subsection{Shrnutí prípadu}

Výsledky iniciálních analýz poměrně jasně ukazují, že ve škole A je učení, přestože se nejedná o explicitní cíl, nedílnou součástí kultury. Učení kontinuálně směřuje ke změně kvality výuky i dobrého jména školy. Motivem učení ve škole i pro školu je komplementárnost tlaku vize školy (prosazované ze strany vedení školy) a motivace jednotlivců být součástí dobrého jádra školy. Organizační kapacita je rozvinuta, organizační bariéry nejsou pocit’ovány jako stěžejní, rozhodující pro učení dospělých je kultura podporující interpersonální (popř. individuální) kapacitu.

\section{Kontrastní př́ípad: Škola B}

\subsection{Charakteristika školy $B$}

Škola B je úplnou základní školou se školní družinou a školní jídelnou. Navštěvuje ji zhruba 350 žáků ve 20 třídách. Na škole pracuje 30 pedagogických pracovníků (z toho 9 speciálních pedagogů) různorodého věkového složení. Pět měsíců před příchodem výzkumníků nastoupila do školy nová ředitelka a její statutární zástupkyně, druhá zástupkyně ředitele (předtím 1 rok zastupující ředitelka) zůstala ve vedení. Na I. stupni pracuje „metodické sdružení“, na II. stupni jsou ,předmětové komise“, tak jak je to ve školách obvyklé.

Škola se věnuje vzdělávání dětí se specifickými poruchami učení - dyslexií, dysgrafií, dysortografií a dyskalkulií, které tvoři 9 tříd. S tím souvisí latentní konflikt vizí školy, daný tím, že nové vedení přichází s ideou inkluzivní školy, zatímco další zainteresovaní preferují ideu speciálních tříd. Vedení je zavázáno ke změně projektem, se kterým ředitelka školy vyhrála konkurz, škola však dosud pracuje v původním režimu. Tento potenciální konflikt se dříve či později opět stane explicitním.

\subsection{Iniciační momenty organizačního učení}

Např́íc školou B je sdíleno povědomí, že hlavní devizou školy je kvalitní péče o žáky se specifickými vzdělávacími potřebami, což dává škole šanci obstát v městském kontextu na „trhu“ základních škol. Tato skutečnost je i hlavním stimulem k učení, jakkoliv je prŕstup učitelů $\mathrm{k}$ této věci rozmanitý (viz individuální kapacita $\mathrm{k}$ učení). Dalším tradičním stimulem k učení jsou - jakkoliv to není reflektováno - jednotlivé akce školy, včetně akcí s přesahem do města/regionu, jako např́klad soutěže žáků se specifickými vzdělávacími potřebami. Novým impulzem je tlak na rozvoj predmětových komisí iniciovaný novými členkami vedení školy na základě kritického postoje k současnému stavu. 


\subsection{Identifikovaná témata organizačního učení}

Mezi tématy pro učení zasahující celou školu či její významnou část je opět významným fenoménem sdílená - byt' dosti obecná - představa o nutnosti kvalitní péče o děti se specifickými vzdělávacími potřebami. K ní se vztahují i další témata, jako jsou problémy každodenního vyučování a kázně ve třídách či podpora začínajících učitelů. Jako méně významné se jeví otázky metodiky, učebnic a pracovních materiálů a zavádění výukových technologií do výuky. Učení je explicitně reflektováno u několika konkrétních vzdělávacích aktivit, jako jsou kurzy k novým výukovým technologiím či jednorázové vzdělávání $\mathrm{k}$ tématu šikany. Reflexe přínosu vzdělávání se nese v rovině pocitů, ne konkrétních poznatků či efektů vzdělávání.

\subsection{Organizační, interpersonální a individuální kapacita $k$ učení}

Pro organizační kapacitu k učení je charakteristická skutečnost, že škola nemá funkční sborovnu, jen místo pro shromažd’ování informací a místo setkávání skupin učitelů či celého sboru je určováno ad hoc. To spolu s dalšími skutečnostmi naznačuje, že organizační kapacita k učení je ve škole B limitovaná. Významnou skutečností je, že předmětové komise na druhém stupni školy jsou formální, maximálně se v nich řeší akutní problémy (některé komise jsou dokonce jednočlenné). Metodické sdružení na prvním stupni je aktivnější a více otevřené ke sdílení a vzájemné podpoře. To dokládá vyjádření zástupkyně ředitelky, učitelskou skepsi vůči potřebnosti těchto struktur pak dokumentujeme vyjádřením učitelky druhého stupně:

\section{ZÁSTUPKYNÉ ŘEDITELKY (škola B):}

„, Metodické sdruženi funguje velice dobře, predmètové komise jsou nesmirně roztřištěné tady v této škole. Někdy předmětovou komisi tvoři jeden člověk, což je k ničemu. Ale více méně to fungováni bylo formální, takže jsme se na všem potom dohodli. Ale stejně, oni většinu věcí řešili ti lidi na chodbách a tak operativně ..., ale že by se sešli, nějak koncepčněji pracovali... “

UČITELKA (II. stupeň, 19 let praxe, škola B):

„Tak jako já nejsem zastáncem děláni takových těch jako oficiálnich schiozek, ale řikáme si, jaks látkou nebo si pưjčujeme třeba materiály. “

Pro interpersonálni dimenzi kapacity korganizačnímu učení je ve škole B rozhodující „kabinetní kultura“, která spojuje učitele na základě blízkosti (někdy lidské, někdy aprobací). Za funkční je ve škole považována komunikace $\mathrm{z}$ očí do očí, ale ta se odehrává zpravidla nahodile, např. o přestávkách či v jídelně. Celoškolní aktivity pro žáky, jako např. mezitřídní projekty, jsou ve škole novinkou zaváděnou novými členkami vedení jednak ve prospěch žáků, ale také pro potenciál sbližovat dospělé. Tyto ostrůvky komunikace jsou potenciálním př́slibem pro rozvoj interpersonální kapacity k učení. Na druhou stranu je však varujícím momentem odpor ke sdílení a obavy ze vzájemných hospitací.

\section{TAZATEL:}

„,Vy jste zminila ty vzájemné hospitace. Je to i nějak podporováno ze strany vedení? Je to nějak třeba formalizováno nebo je to čistě na nich?"

ZÁSTUPKYNĚ ŘEDITELKY (dřive zastupujicí ředitelka)

„Je to čistě na nich, ano. Dali jsme jim možnost, že mají chodit. Několikrát samožrejmě bylo pripomenuto, že mají možnost. “ 
TAZATEL:

„,Ted’ka se hodně mluví o kolegiálních hospitacích. Viděla jste někdy kolegy při práci? “

UČITELKA (II. stupeř, 19 let praxe, škola B):

„No neviděla. Ale myslím si, že to určitě má svưj smysl, protože člověk vždycky od spousty lidí může prevzit, no... Ne, neviděla jsem. "

TAZATEL.: „A u Vás se někdo byl podivat? ,,

UČITELKA: „No, nebyl. Jako kromě vedení. Z kolegů nebyl“

ZÁSTUPKYNĚ ŘEDITELKY (̌̌kola B):

(...) vzájemné hospitace, o to moc zájem není, třeba mně ř́kali, když jsem byla na hospitaci: „Když príjdete do hodiny, to mně nevadí, ale kdyby méla prijiít kolegyně, tak mnè to děsně vadí. Strašnè mě to stresuje a zavazuje. " Já vím, že to neni nikdy príjemné, když Vám tam vzadu sedí, jo, čeká na každé sli̊vko. Záleži na typu učitele a tak."

Individuální kapacita k organizačnímu učení není ve škole B silněji spojena s organizačním učením. Individuální profesní rozvoj je vnímám odtrženě od potřeb školy a jakkoliv je vnímána potřeba speciálních pedagogů, členové sboru na možnost získat formální vzdělání v tomto oboru neslyší. O dalším vzdělávání se rozhoduje spíše pocity, než racionální reflexí potřeby a př́padně efektů vzdělávání. Učení je explicitně spojována pouze $\mathrm{s}$ dílčími vzdělávacími aktivitami.

\section{TAZATEL:}

„Já se chci ještě zeptat na dalši vzdělávání, jak to tady ve vaši škole funguje. (...) “

UČITELKA (II. stupeñ, 19 let praxe, škola B):

„No, jak to běži? Paní zástupkynè mi rozesílá nabidky, co chodí, většinou to rozesilá už adresně, takže mně pošle nějakou nabídku na matematiku a my si z toho vybíráme a pak samožrejmě, když se mi tam něco libí a považuji, že by mi to něco dalo, tak se jdu zeptat, jestli tam na to jsou penizky. “

\subsection{Jak je organizační učení ve škole podporováno?}

Potřeba vedení a podpory organizačního učení je ve škole B především (v některých ohledech téměř výhradně) vyjadřována novými členkami vedení, prozatím spíše ve formě vize. Tato vize je sboru opatrně dávkována, vedení pro ni začíná hledat důvěru. Konkrétní návrhy odtud směřují $\mathrm{k}$ přestrukturování a rozvoji funkčnosti předmětových komisí, k organizaci vzdělávacích akcí pro sbor či jeho podstatnou část přímo ve škole. Vedení školy také prezentuje potřebu řízení kontrolou a hospitacemi. Zajímavým prvkem je nástup nových členek vedení do studia speciální pedagogiky s dvojím cílem: doplnit kvalifikaci sboru a působit ve škole jako vzor ve vzdělávání a rozvoji. A konečně se hovoří o rozvoji školy prostřednictvím investic do materiálního vybavení školy.

\subsection{Shrnutí prípadu}

Ve škole B vládne kultura postavená spíše na izolované práci učitelů. Komunikace mezi učiteli je limitovaná. Mechanismy podpory učení jsou slabé i proto, že nové vedení školy se ve škole teprve orientuje a opatrně hledá podporu pro své návrhy na změnu. Stávající kapacita k organizačnímu učení ve škole B je tedy zjevně limitovaná. 


\section{Předběžné závěry z př́ípadových studií}

Domníváme se, že dosavadní vývody z př́ípadových studií potvrzují vhodnost zvoleného designu. Design př́ípadové studie otevřel možnost vnímat roli specifické konfigurace atributů školy podporujících organizační učení v jednotlivých školách. Data z př́ípadových studií si také vyžádala doplnění teoretické základny výzkumu. Ačkoliv tato fáze výzkumu není dosud uzavřena a bude pokračovat další (kontrastní) prŕípadovou studií, už nyní krystalizují předběžné interpretace vázané na teoretické koncepty organizačního učení. Výstupy z analýzy případových studií odkazují k následujícím konceptům:

Předně jde o koncept kapacity pro organizační učení, který už byl diskutován výše. Tento koncept se stal základním analytickým nástrojem pro tuto fázi analýzy, kde umožnil odlišit existenci potenciálu k organizačnímu učení a samotného organizačního učení. Jakkoliv jsou tyto dvě věci (potenciál a realita) bezpochyby spojeny, tam, kde kapacita chybí, k čemuž má zjevně blíže škola $B$, je předčasné hledat také procesy organizačního učení v celé jejich šiři a hloubce.

Zajímavou možnost interpretace nabízí také koncept organizačního učení v jedné, dvou či tř̌ech smyčkách (srov. Argyris, Schön, 1996). Učení v první smyčce (modifikace chování za účelem splnění cíle) patř́ ke každodenní realitě práce učitele a školy, jakkoliv se liší v jednotlivých školách míra učení a jeho mechanismy. Učení ve druhé smyčce, tzn. mj. učení se schopností modifikovat cíl, ke kterému má učení napomoci, už není nutně ve zkoumaných školách zastoupeno. Učení ve prospěch změny školy (třetí smyčka) a k tomu směřující modifikace chování a cílů činnosti, je pak obtížně k nalezení v obou prŕípadech. Jakkoliv jsou mezi školami rozdíly v mnoha aspektech (šíře zapojení sboru, ochota otevírat hlubší témata apod.), je třeba říci, že je velmi obtížné na základě zjevných znaků rozlišovat školy podle přítomnosti smyček vyšších učení a rozhodně tak nelze činit mechanicky.

A konečně se ukazuje se kritická role vedení procesů organizačního učení. Přrípadové studie upozorňují, jak významný je prvek vedení procesů organizačního učení ve smyslu nastavení, udržování a trvalé podpory mechanismů organizačního učení. I tento moment si ale žádá hlubšího vytěžení v analýze př́ípadových studií, případně v dalších fázích výzkumu.

\section{Literatura}

Argyris, C., \& Schön, D. (1996). Organizational learning II: Theory, method and practice. Reading, Mass.: Addison Wesley.

Collinson, V., Cook., T. F., \& Conley, S. (2006). Organizational learning in schools and school systems: Improving learning, teaching and leading. Theory Into Practice, 45(2), 107-116.

Dalin, P., Rolf, H. G., \& Kleekamp, B. (1993). Changing the school culture. London: Cassell.

Goh, S. C., Cousins, B., \& Elliott, C. (2006). Organizational learning capacity, evaluative inquiry and readiness for change in schools: Views and perceptions of educators. Journal of Educational Change, 7(3), 289-318.

Leithwood, K., \& Louis, K. S. (Eds.). (1998). Organizational learning in schools. Lisse: Swets \& Zeitlinger.

Marsick, V. J., \& Watkins, K. E. (1994). The learning organization: An integrative vision for HRD. Human Resource Development Quarterly, 5(4), 353-360.

Miovský, M. (2006). Kvalitativni prístup a metody v psychologickém výzkumu. Praha: Grada.

Pol, M. (2007). Škola v proměnách. Brno: MU v Brně.

Sedláček, M. (2007). Př́ipadová studie. In R. Švaříček \& K. Šed'ová et al. Kvalitativní výzkum v pedagogických védách. Praha: Portál.

Stake, R. E. (1995). The art of case study research. Thousand Oaks: Sage Publications.

Verbiest, E. (2002). Collectief leren in scholen. Fontys: Tilburg.

Yin, R. K. (2003). Case study research: design and methods. Thousand Oaks: Sage Publications. 


\section{Kontakt}

prof. PhDr. Milan Pol, CSc.

Mgr. Lenka Hloušková, Ph.D.

doc. PhDr. Bohumíra Lazarová, Ph.D.

doc. Mgr. Petr Novotný, Ph.D.

Mgr. Martin Sedláček, Ph.D.

Masarykova univerzita

Filozofická fakulta, Ústav pedagogických věd

A. Nováka 1, 60200 Brno

e-mail:pol@phil.muni.cz

hlouskov@phil.muni.cz

lazarova@phil.muni.cz

novotny@phil.muni.cz

msedlace@phil.muni.cz

\section{Bibliografické údaje}

Pol, M., Hloušková, L., Sedláček, M., Lazarová, B., \& Novotný, P. (2011). Vedení procesů organizačního učení ve škole: případové studie. In T. Janík, P. Knecht, \& S. Šebestová (Eds.), Smišený design vpedagogickém výzkumu: Sborník př́spěvků z 19. výročni konference České asociace pedagogického výzkumu (s. 109-117). Brno: Masarykova univerzita.

Dostupné z:

http://www.ped.muni.cz/capv2011/sbornikprispevku/PolHlouskovaSedlacekLazarovaNovotny.pdf

doi: 10.5817/PdF.P210-CAPV-2012-49 